\title{
The Function of English on the Spread of Chinese Tea Culture under the Background of Cross-Border E-Commerce
}

\author{
Jing Tan \\ Department of Basic Courses, Guangdong Communication Polytechnic, Guangzhou, China \\ Email: mlbsabc@sina.com
}

How to cite this paper: Tan, J. (2017) The Function of English on the Spread of Chinese Tea Culture under the Background of Cross-Border E-Commerce. Open Journal of Social Sciences, 5, 123-126. https://doi.org/10.4236/jss.2017.52012

Received: January 21, 2017

Accepted: February 11, 2017

Published: February 14, 2017

Copyright $\odot 2017$ by author and Scientific Research Publishing Inc. This work is licensed under the Creative Commons Attribution International License (CC BY 4.0).

http://creativecommons.org/licenses/by/4.0/ (c) (i) Open Access

\begin{abstract}
China is a rising power all over the world in the $21^{\text {st }}$ century. With the rising international status of China, more and more overseas countries want to learn and master Chinese symbols, and the oversea spread of Chinese culture is becoming a current hot topic. Chinese tea is famous all over the world for a long time with its various kinds and good tastes. But the export of Chinese tea often meets difficulties. Inspecting the international tea market, it is not hard to find that all countries have their own comparative advantages, especially for small southeast Asian countries which make a national effort to develop the tea foreign trade in order to meet the needs of national economy. All these bring a great challenge to the export of Chinese tea that how to convey our tea information to overseas customers accurately and how to improve their product experience. To solve these difficulties, China needs to attach great importance to English. The specific solutions include building a third party translation team, establishing tea culture translation standards and expanding the business scope of the tea culture.
\end{abstract}

\section{Keywords}

Cross-Border E-Commerce, Chinese Tea Culture, English, Foreign Customers

\section{Introduction}

Chinese tea has long been famous on the international stage, and Europe is the main export market. Chinese tea is connected with Chinese culture of a quiet and healthy way of life. But due to information blockade, industry standards, export policies and other factors, Chinese tea has always been difficult to have a big breakthrough in the field of export. Prices have been in a weak position. The cross-border e-commerce can change the current situation of Chinese tea export [1]. 
Under the strategy of our country's "Internet+", cross-border e-commerce has become an important part of our foreign trade and exports. Cross-border ecommerce concentrate business flow, logistics, cash flow and information flow as a whole, and greatly save the transaction cost in the traditional foreign trade activities. So the bulk cargo export trade of our country can completely implement by relying on cross-border e-commerce. Chinese governments and enterprises should also notice that e-commerce has some disadvantages such as customer experience is not good comparing to the traditional foreign trade activities, as in the development of cross-border e-commerce, while English can improve this situation.

\section{The Commercial Value of Chinese Tea Culture under Cross-Border E-Commerce}

\subsection{Cater to the Current Consumption Environment}

Overseas customers who buy our Chinese tea mainly include two kinds, one is the overseas Chinese citizens and ethnic Chinese, and the other is foreign middle-class people. For the former customers, they are already influenced by Chinese tea culture themselves to some extent, so they will have a natural demand for culture when they are buying tea. While to the latter customers, they are the backbone of the foreign local country's consumption, and their consumption levels determine their demand diversities, while to know Chinese tea culture is one of their demands. So Chinese tea culture caters to the current consumption environment [2].

\subsection{Enhance the Market Recognition of Chinese Tea Culture}

Although many products abroad can be included as tea in the context of Chinese language, there are still significant differences between the functions, appearance and production conditions of those products. It will be strict requirements for foreign customers to build market recognition through the functions, appearance and production conditions of tea. Because the ways of recognition are very professional [3]. However, if Chinese enterprises put tea culture elements into the tea sales, it will be easier for foreign customers to recognize tea.

\subsection{Enrich the Tea Products}

As the home of tea, the tea products of China spread all over the world include various kinds of tea and tea set. It also contains rich spiritual connotation as China called tea culture. It helps people to be quiet and empty spiritual in the noisy world. With the rapid development of global economy, and faster pace of people's daily life nowadays, people around the world are eager to pursue a healthier way of life. While tea has natural pollution-free and health care functions, and its unique way of drinking is superior to the popular carbonated Drinks all over the world.

So facing the fierce competition of the international tea market situation, establishing tea brand will help to keep the stability of consumer groups. Chinese enterprises should consider the common culture as the idea and material ele- 
ments of building tea brands in order to arouse the consuming desires of foreign customers when they get interests.

\section{English Functions on the Spread of Chinese Tea Culture}

\subsection{Promote the International Spread of Tea Culture}

As described above, the spread of tea culture can meet the demands of foreign customers. But in face of the non-Chinese consumers, Chinese enterprises need to nurture them with Chinese tea culture at the beginning. So, to solve the plight of language communication, English can set up international channels for spreading information between our country and foreign countries. Under the background of cross-border E-commerce, English functions can be realized through E-commerce platform and sales packages. The E-commerce platform can complete the tea products' sale by the mode of B2C (Business to Customers) [4]. While as to the sales packages, they can enhance their consumption desires when informing the foreign customers of using process.

\subsection{Promote the Tea Culture to Be Better Received by Consumers}

Chinese tea culture is made up of explicit and implicit elements. The explicit elements includes various kinds of tea and tea sets, while the implicit elements are about the inner qualities of tea and about a way of life. And China should exhibit the explicit culture to foreign customers in order to enhance the market recognition of Chinese tea in the international market. To be specific, Chinese governments and enterprises can combine the tea growing natural environment with local famous places of interest on the E-commerce platform and in sales packages. They can also present our tea culture by the form of vivid Chinese ink painting, with English description aside, by this way can let them better understand Chinese tea culture.

\section{Analysis on the Difficulties of Culture Spread under Commercial Mode}

There are two ways of translating Chinese into English-literal translation and liberal translation. Literal translation is difficult to describe implicit elements of Chinese tea culture, such as the natural view of unity of heaven and humans. Foreign customers who are affected by ancient Greek philosophy can not understand the natural view of unity of heaven and humans. So literal translation will encounter challenges when expressing the Chinese tea culture information. While liberal translation is to express the information by translators' own understandings and experience. But this way can not guarantee that the translators can master the tea culture accurately.

\section{Suggested Solutions}

\subsection{Build a Third Party Translation Team}

Under the background of "Internet+" strategy, E-commerce in our country has 
been growing. In order to match the international market, the application of English should be simplified and professional. So building a third party translation team is needed. At present, many consulting companies can also undertake English translating work, but most of the information fragments can not meet the requirements of the market. So Chinese enterprises need to build a third party translation team according to the requirements of cross-border E-commerce.

\subsection{Set the Translation Standards of Tea Culture}

It is a difficult work to set the translation standards of tea culture which also needs governments' recognition. So business departments, tea companies and English translation expert groups should work together in order to complete a set of English translation standards of tea culture. As described above, most of English translation can not reach Chinese contexts. So the English translation standards should be developed first from the implicit cultural elements. In order to improve the efficiency of the formulation of standards, Chinese enterprises should divide the formulation process into different modules [5].

\section{Conclusion}

The popularization and development of tea culture in the world make the vocabulary about tea grow in English system. In the context of economic globalization, our country's openness is deepening. More and more scholars pay attention to translation fields. It will hinder the tea culture communication if the translation is not accurate. Nowadays, E-commerce companies pay much attention to good interactions with consumers, so English is playing a more and more important role.

\section{References}

[1] Jiang, X.J. and Jiang, Y. (2014) The Discussion on the Doctrine of the Mean Thought and Its Translation Strategies in Tea Classics. Language Teaching, 3, 61-66.

[2] Jiang, X. and Yang, D.H. (2012) The Intertextuality in Translation of Sequel to the Classics of Tea. Journal of Liaoning Normal University (Social Science Edition), 3, 92-95.

[3] Liu, J. (2014) Research on the Tea Name Translation and Countermeasures under the Guidance of Skopos Theory. Journal of Language and Literature Studies (Foreign Language Education and Teaching), 4, 51-54.

[4] Ding, H., Yang, Q.L. and Liu, B. (2013) Exploration to B2C E-Commerce Marketing Strategies. Modern Trade and Industry, 14, 65-67.

[5] Luo, H.M. (2013) Discussions on Accurate Marketing of E-Commerce Based on Data. Journal of Wuhan Business Suit School, 3, 46-48. 
Submit or recommend next manuscript to SCIRP and we will provide best service for you:

Accepting pre-submission inquiries through Email, Facebook, LinkedIn, Twitter, etc. A wide selection of journals (inclusive of 9 subjects, more than 200 journals)

Providing 24-hour high-quality service

User-friendly online submission system

Fair and swift peer-review system

Efficient typesetting and proofreading procedure

Display of the result of downloads and visits, as well as the number of cited articles Maximum dissemination of your research work

Submit your manuscript at: http://papersubmission.scirp.org/

Or contact jss@scirp.org 